\title{
Seed Formation Theory in Alexandria Era
}

\section{Hanan Youssef}

\section{Faculty of Arts, Alexandria University}

\section{Introduction}

Formation of seeds or sperms $(\mathrm{S} \pi \varepsilon \dot{\varepsilon} \rho \mu \alpha)$ was a matter of debate since ancient times, for example, Ancient Egyptians believed that sperm originated in the bones of a man because bones were white (and so was semen). They were under the impression that all white-colored parts of the infant were made solely with the bone of the man: eyes, teeth, and internal bones $^{(1)}$.

During the fifth and fourth centuries B.C, there were many theories trying to explain how seeds were formed, the most accepted theories during that era were:

\section{First theory: Encephalogenetic Theory: "The Pythagorean Theory":}

Seeds are totally or partially cerebral in origin that reach male reproductive system through a network of blood vessels starting from the brain and passing through the ears and the neck to the spinal column, then to the loin and finally to the penis ${ }^{(2)}$.

( $\left.{ }^{1}\right)$ Tiffany Quebral, The History of the semen Analysis, BCYB, 2016, p. 15.

$\left({ }^{2}\right)$ Diogenes Laertius viate Philosophorum , 8.28.

Cf: Hermann Diels, Walther Kranz, Die Fragmente der Versokratiker , $6^{\text {th }}$ ed., 58B1a, 3vols. C .(Berlin/zurich,1951). 


\section{Seed Formation Theory in Alexandria Era}

According to that theory, Hippocratic doctors thought that any injury to the previously mentioned vascular network starting in the brain and ending in the male genitalia cause infertility ${ }^{(3)}$.

They gave an example, when an injury occurs to the blood vessels beside the ears like during blood letting. This will lead to scar tissue formation and failure of the seeds to descend down and continue their pathway to the genitalia leading to impotence ${ }^{(4)}$.

\section{Second Theory: Pangenesis Theory by the Hippocratic Corpus}

Sperms are not only cerebral in origin but also from anywhere and everywhere in the body. In Hippocratic work: is "on airs, waters and places" states that seeds come from all parts of the body, healthy seed from healthy parts, diseased seed from diseased parts. There, the seeds are transmitted from the father to the children, e.g. colored eyed father will result in colored eyed children ${ }^{(5)}$.

$\left({ }^{3}\right)$ Hippocrates On seed, 2

"The greatest amount of seed comes from the head along the ears into the spinal marrow. This duct is, however, hardened as a result of the formation of a scar after the cut has been made".

Cf : Lonie, The Hippocratic Treatises "On Generation"

"On the Nature at of Child", Berlin, 1981.

$\left(^{4}\right)$ Hippocrates , "Airs, Waters and places", 22.

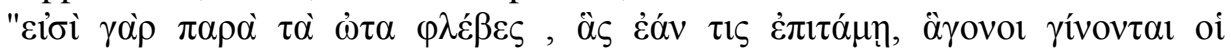

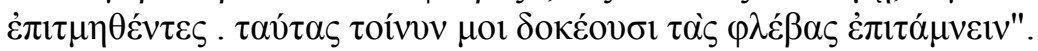

"for, by the side of the ear vessels and if someone cuts them [i.e for the purpose of bloodletting,] those so cut become important".

Cf : Hippocrates ,Epidemics , 6.5.15 on Bloodletting behind the ear.

$\left(^{5}\right)$ Hippocrates, "On Airs, Waters and places", 14.

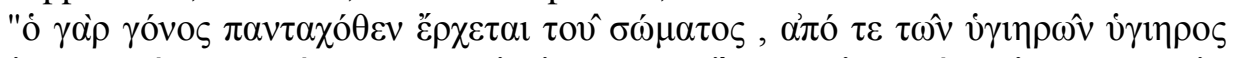

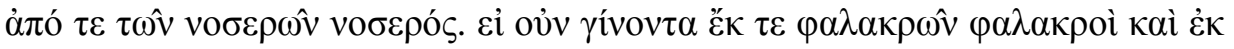

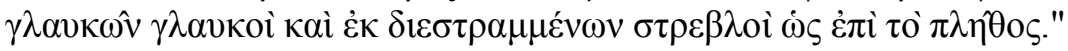

"For the seed comes from all parts of the body, healthy seed from healthy parts, diseased seed from diseased parts. If, therefore, bald parents have for the most 


\section{Hanan Youssef}

\section{Third theory: Hematogenous Theory "Aristotle":}

Seeds are the residue derived from the nourishment; or to make it clearer, it is the most perfect component of our food, but how seeds were formed from food? Aristotle claimed that after the mashing of the food, it passes to the stomach where it is ripened by the means of natural gastric heat, then it passes to the heart in a liquid form where it is changed and mixed with pneuma - after which it is transported through the vascular system to all the parts of the body to maintain life. The surplus of the blood undergoes a process of concoction resulting in sperm formation ${ }^{(6)}$.

After shedding light on the different theories of seed formation in pre - Alexandrian era, it is now the time to show the role of the first anatomist in ancient Alexandria's medical school, Herophilus of Chalcedon, the father of anatomy ${ }^{(7)}$. He completely rejected the encephalogenetic theory by Pythagorean, and the Pangenesis theory by Hippocratic Corpus but he found that the Hematogenous Theory of Aristotle is the most accepted theory ${ }^{(8)}$.

part bald children, grey-eyed parents grey-eyed children, squinting parents squinting children." =

= Cf: Hippocrates, "on the sacred disease", Ch. 5.

Cf : Aristotle, "on Generation of Animals"1.17.721b7---722a1

We found that Aristotle himself rejected pangenesis theory.

$\left({ }^{6}\right)$ Aristotle , Generation of Animals, 1.16---19.721b26----727b30

See also Parts of Animals 2.6.651b20f.

(7) Noel Si-Yang Bay and Boon- Huat Bay, Greek Anatomist Herophilas . the father of Anatomy Anat Cell Biol , 2010, 280-283.

$\left({ }^{8}\right)$ Kremer J., the Haematogenous reproduction Theory of Aristotle, PubMed , 2003,2529-35.

- Gelis , D. , History of childbirth, Pregnancy and Birth , Northeastern university press Boston, 1991

- Bullough, V.\& Bullough, B. , Sexual Altitudes; Myth and Realities, Prometheus , Boston, New York ,1995. 


\section{Seed Formation Theory in Alexandria Era}

Vindician gave us five evidences to adapt Herophilus to the hematogenous theory; First evidence: by dissecting genital organs by Herophilus; it was found that these areas contain a large number of blood vessels $^{(9)}$.

So this extra number of blood vessels can carry surplus of blood and this results in seeds formation in the male, also this is present in the female genital system which carries a large number of blood vessels essential for the nourishment of the fetus in the uterus, but after delivery, the blood surplus is needed for the fetus. So the blood is directed towards the breast to start the process of lactation ${ }^{(10)}$.

The end result of the first evidence is that the blood surplus is needed for seed formation.

(9) Vindicianus, Framentum Bruxellense de Semine I lines 7-12.

"Primo igitur, ut Herofilus ait, abruptio corporum hoc testatur quam Graeci $\alpha^{\prime} v \alpha \tau o \mu \eta^{\prime} v$ vocant. etenim seminalium vasculorum interiora atque secretius remota sanguinulenta videntur, sequentia vero sive secunda plurimum a praescriptis demutata sunt, inferiora ac proxima seminis colorem habent. quo probatur in seminales vias sanguinem venire".

"First, then, as Herophilus says, tearing open bodies, which the Greeks called 'dissection' (anatomē), is a witness to this. For the internal parts of the seminal vessels which are also at a more remote distance [sc. From the genitalia] appear full of blood, whereas the ones that follow next are changed very much compared to the aforementioned ones, and the lower, more accessible ones have the colour of seed. This proves that blood enters into the seminal ducts".

$\left({ }^{10}\right)$ Ibid , Lines 13-16.

"Sed earum virtute albescere atque mutatum in seminis transire qualitatem. sicut etiam in feminis post partum, si quid sanguinis nondum fuerit uteri nutrimento consumptum, naturali meatu fluit in mammas et earum virtute albescens lactis accipit qualitatem".

"But then through the power of these ducts becomes white and, having changed, is transformed into the quality of seed. Similarly in females, too, if after child-birth no blood is any longer used up as nourishment for the uterus, the blood flows to the breasts by a natural course and, through the power of the breasts, grows white and takes on the quality of milk". 


\section{Hanan Youssef}

Second evidence: seeds are mainly Hematogenous in origin but this takes a period of time to be formed from blood.So when there are frequent sexual intercourses, there is not enough time for the blood to produce seeds. This results in the emission of blood into the genital system instead of seeds ${ }^{(11)}$.

Third evidence: seeds and blood are considered to be the most important dampness ${ }^{(*)}$ in the human body, and according to the famous saying:"What is the most important comes from what is important" ${ }^{(12)}$, So seeds come from blood.

Fourth evidence: pallor, illness, dizziness and weakness are the manifestations of excessive blood loss - all of the previous manifestations also result from frequent sexual intercourse. This means that there is a close relationship between seeds and blood. ${ }^{(13)}$

$\left({ }^{11}\right)$ Ibid., Lines 17-19.

"Secundo: [cum] illi, qui frequentius usu venerio depurgantur, sanguinis sustinent per seminales vias emissionem, siquidem celeritatis causa essentia sanguinis in seminales venire non sinitur vias".

"Second, men who deplete themselves too frequently through sexual intercourse suffer an emission of blood through their seminal ducts, since the essence of the blood is in fact not allowed to enter into the seminal ducts on account of the speed [sc. of seminal depletion]".

${ }^{(*)}$ This means that seeds and blood are the most important components in the human body containing water.

$\left.{ }^{12}\right)$ Ibid Lines 20-22.

"Tertio summum quicauam ex summon fieri necesse est. summum est autem semen ex omnibus in nobis liquoribus, summus est sanguis. Semen igitur ex sanguine generator".

"Third, anything that is most important must arise from something that is most important. But of all the moistures in us seed is the most important. Blood, too, is most important. Seed therefore is generated out of blood".

$\left({ }^{13}\right)$ Ibid Lines 23-25. = 


\section{Seed Formation Theory in Alexandria Era}

Fifth evidence: As the blood is clotted once it escapes out of its normal vascular system, this is exactly what happens when seeds come out of the male genital tract to be deposited into the female genital system ${ }^{(14)}$.

Controversy appeared regarding if the five evidences in Vindician 's fragment belonging to Herophilus, especially that Vindician starts with a preliminary phrase about Alexander, one of the disciples of Aesclepiades, he says in his $1^{\text {st }}$ book "About the seed" that the essence of the seed is blood $^{(15)}$.

Although he does not mention Herophilus by name in any of these evidences except in the first evidence, we find that the mentioned evidences are consistent with the theories and practices of Herophilus more

= "Quartum: quicum que flebotomantur, sustinent post sanguinis detractionem pallorem, tenuitatem, debilitatem. Haec etiam peracta venere corpora comitantur, siquidem semen ex sanguine fieri videtur".

"Fourth, whoever is subjected to bloodletting suffers from paleness, loss of weight, and weakness, after the blood has been drawn. These things also attend bodies that have been exhausted in sexual intercourse, since seed in fact seems to be formed from blood".

$\left({ }^{14}\right)$ Ibid Lines 26-29.

"Quintum: semen matrici appositum congelatur ut declarant corporis abruptiones, quod est signum seminis [atque] essentiae de sanguine venientis et ad suam originem redeuntis, quippe praeter sua vascula constitute".

"Fifth, when seed is placed in the uterus, it congeals, as dissections of the body make clear. This is sign of the fact that its essence comes from the blood and that it returns to its own origin because it has been placed outside its own vessels".

$\left({ }^{15}\right)$ Vindicianun, op. cit., Lines 1- 3 .

"Alexander amator veri appelatus, discipulus asclepiadis, libro primo de semine spumam eius essentiam dixi diogenis placitis consentiens. item Erasistratus et Herofilus essentiam seminis dicunt sanguinem".

"Alexander, called Philalethes', a pupil of Ascelpiades, says in Book 1 of his 'On Seed' that the essence of the seed is the froth of the blood, and therein he agrees with the opinion of Diogenes Erasistratus and Herophilus likewise say that the essence of seed is blood". 


\section{Hanan Youssef}

than any other author mentioned in the preliminary phrase regarding the defendants of the hematogenous theory regarding seed formation.

For example, the First evidence does not only mention the name of Herophilus, but also mentions two elements among the elements of his expertise which are anatomy and male genitalia, among the believers in the Hematogenous theory mentioned in that part are Erasistratus who was a pioneer of anatomy but he was not famous for dissecting reproductive organs.

The second evidence: is also related to a problem that is connected to Herophilus which is the contribution of a number of body organs to the formation of seeds via "its transportation system "(16) and this subject wasn't discussed by Diogenes and Erasistratus and Alexander ${ }^{(17)}$.

The third evidence: regarding blood and seeds was the most important thing that was supposed to be presented by any of the defendants of the Hematogenous theory. The forth evidence about bloodletting is a statement based on the observation of the practices of others, that might be presented by any of the philosophers and physicians that were mentioned by Vindician. But if it was based on a personal clinical or medical observation

$\left({ }^{16}\right)$ Rufus Ephesim , De Styriasmo et gonorrhea 7-8.

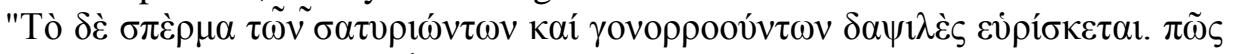

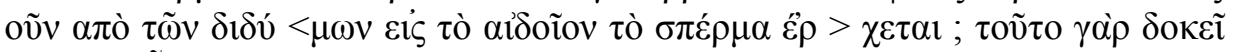

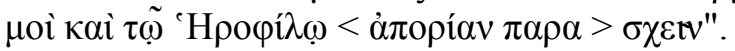

"The seed of people suffering from hyper sexuality and spermatorrhoea [gonorrhoiba] is found to be excessive. How then does the seed get from the testicles to the penis? For this seems to me to have provided Herophilus, too, with an insoluble difficulty".

It is striking that a variation of this second argument (i.e. that excessive intercourse results in the ejaculation of blood or 'unconcocted seed", but not of (seed) was also used by Arisototle to prove that seed derives from blood: Generation of animals I.19.726b7-11.

$\left({ }^{17}\right)$ Diogenes of Apoollonia , b4a24 - 27 DK. 


\section{Seed Formation Theory in Alexandria Era}

like the $1^{\text {st }}$ and $5^{\text {th }}$ evidences, then we do not find anyone except Herophilus who had used bloodletting as a Therapeutic mean for treatment especially that we know that Erasistratus refused to use bloodletting as a therapeutic apparatus ${ }^{(18)}$.

Finally, the fifth evidence is not only introducing anatomy, but also the subject which Herophilus is the most trusted authority concerning it more than all the other people who were mentioned by Vindician, which are the female reproductive organs ${ }^{(19)}$.

\section{Conclusion}

In the end, if Herophilus accepted Aristotle's theory that says that the seeds originated from blood, however he also showed his independence from Aristotle, as whereas Aristotle thought that the production of seeds is completed in the blood vessels and he never attributed any part of it to the testicles or the seminal duct, Herophilus, on the other hand, thought that both of them play an important role in the generation of sperms ${ }^{(20)}$.

$\left({ }^{18}\right)$ Galen, De venae Sectione adersus Erasistratum, $x 1$.

$\left({ }^{19}\right)$ Soranun, Gynaecia 3, prooem. 3.4.

$\left({ }^{20}\right)$ Galenus, De Semine 1.16.

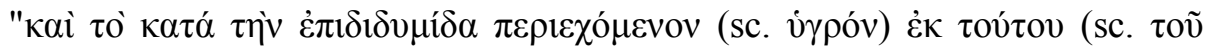

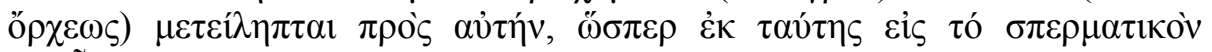

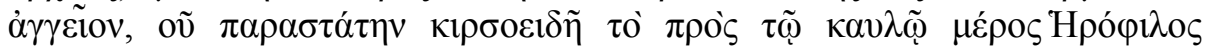

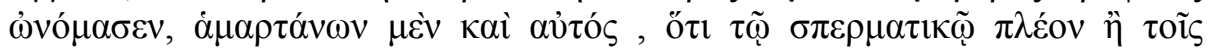

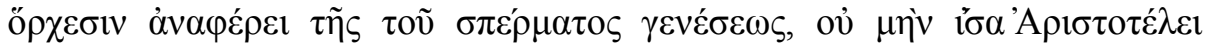

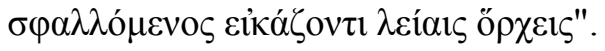

"And the seminal fluid contained in the epididymis is transferred from the testicle to the eipidymis, just as it is from there into the seminal vessel. To the part of the seminal vessel bordering on the penis, Herophilus gave the name 'varicose assistant' ( $\pi \alpha \rho \alpha \sigma \tau \alpha \dot{\tau}\rceil \varsigma \kappa \iota \rho \sigma o \varepsilon \imath \delta \tilde{\eta} \varsigma)$. Even Herophilus is mistaken inasmuch as he attributes a greater role in the generation of seed to the seminal vessel than to the $==$ testicles, but he was not quite as mistaken as Aristotle, who compared the testicles to loom weights". 


\section{Hanan Youssef}

It is a fact that Galen criticized Herophilus for not attributing a greater role in the production of the seeds to the testicles more than the seminal vessel but Galen added quickly that at least Herophilus did not make mistakes like Aristotle who compared between testicles to loom weights. ${ }^{(21)}$

In the theory of Herophilus, the male seeds appear to be only incompletely formed when it reaches from the blood vessels to the testicles in a continuous process of more ripening, it passes from the testicles to the epididymus, and then the seeds descend to the ductus deferens and the seminal vessels.

Herophilus has given clear and satisfactory details regarding the mechanism of the transportation of the seeds from the testicle to the penis; Rufus concludes that this resulted in Herophilus facing unsolvable difficulty. ${ }^{(22)}$

$\left.{ }^{21}\right)$ On The Testicles on loom weights see Aristotle, Generation of Animals 1.4.717a14-36.

$\left({ }^{22}\right)$ Rufus . Ephesius, De Satyriasmo et gonorrhoea 7-8. 


\section{Seed Formation Theory in Alexandria Era}

\section{WORKS CITED}

Aristotle, "On Generation of Animals", A. L. Peck, London, 1993.

Bullough, V. \& Bullough, B., Sexual Altitudes; Myth and Realities, Prometheus , Boston, New York ,1995.

Diogenes Laertius, Vitae Philosophorum, ed. H. S. Long (Oxford, 1964).

Dumas, C., et al. C R Biol, Fertilization and early seed formation, PubMed, 2008.

Galenus, De Semine, ed. Ph. De Lacy, CMG (Berlin, 1968).

Gelis , D., History of childbirth , Pregnancy and Birth , Northeastern university press Boston, 1991

Hermann Diels, Walther Krans, Die Fragmente der Versokratiker, $6^{\text {th }}$ ed., Berlin, 1951.

Hippocrates, "Epidemies", W. H. S. Jones, London, 1995.

Hippocrates, "On airs, Waters, Places", W. H. S. Jones, London, 1995.

Hippocrates, "On Generation", Lonie, Berlin, 1981.

Hippocrates, "On the Nature of Child", Lonie, 1981.

Jean Baptiste Bonnard, Male and Female Bodies According to Ancient Greek Physicians, CAIRN, 2013.

Kremer J., the Haematogenous reproduction Theory of Aristotle , PubMed, 2003,2529-35.

Noel Si-Yang Bay and Boon- Huat Bay, Greek Anatomist Herophilas . the father of Anatomy Anat Cell Biol , 2010, 280-283

Rufus Ephseius, De Satyriasmo et gonorrhoea, G. Daremberg, G. E. Ruelle, Paris, 1879.

Sergio Musitelli and Ilaria Bossi, A Brief Historical Survey of Generation (From Hippocrates (469- 399 B.C.) to The Controversy between "Spermatists" and "Ooists"), Annals of Reproductive Medicine and Treatment, Italy, 2016.

Vindicianus, Fragmentum Bruxellense de, Semine, Wellmann, Berlin, 1963. 